\title{
Quantification of Colletotrichum fioriniae in Orchards and Deciduous Forests Indicates It Is Primarily a Leaf Endophyte
}

\author{
Phillip L. Martin and Kari A. Peter ${ }^{\dagger}$ \\ Department of Plant Pathology and Environmental Microbiology, Fruit Research and Extension Center, The Pennsylvania State University, \\ Biglerville, PA 17307 \\ Accepted for publication 27 July 2020.
}

\begin{abstract}
Colletotrichum fioriniae of the C. acutatum species complex is an important hemibiotrophic pathogen of vegetables and fruits in temperate regions worldwide. In apple, it is one of the primary species responsible for bitter rot disease. Understanding the disease cycle is complicated because many broadleaf plants can be hosts of $C$. fioriniae. By detecting and quantifying rain-splashed $C$. acutatum species complex conidia in more than 500 samples from heavily bitter-rot-infected apple orchards and nearby forested woodlots over two summers, we show that conidial quantities were higher in the woodlots than in the orchards. Testing of more than 1,000 surface-disinfected leaves of apple and 24 different forest plant species showed that overall $C$. fioriniae was an abundant leaf endophyte, with high variation in leaf colonization area. Endophytic
\end{abstract}

ABSTRACT

Colletotrichum fioriniae (Marcelino \& Gouli), a member of the C. acutatum species complex (SC) (Damm et al. 2012), is an ascomycete fungus that is a pathogen of primarily aboveground tissues of more than 100 plant species of temperate regions worldwide (Farr and Rossman 2019). As pathogens, species in the C. acutatum SC are known as hemibiotrophs, where initial penetration of plant tissue via appressoria is followed by a period of time that, depending on the context, is known as a biotrophic, latent, or quiescent phase, after which the infection turns necrotrophic and rot symptoms become obvious (Damm et al. 2012; Peres et al. 2005; Wenneker and Thomma 2020). However, the $C$. acutatum SC has also been isolated from leaves of many broadleaf plants on which it has never been identified as a pathogen and as such is considered to be an endophyte or epiphyte (Berrie and Burgess 2003; Børve and Stensvand 2017; Frare et al. 2016; Freeman et al. 2001; Marcelino et al. 2009; Parikka and Lemmetty 2009, 2012; Parikka et al. 2014; Stensvand and Børve 2008).

While most studies of the C. acutatum SC have been in relation to its role as a pathogen, nonpathogenic interactions on the surface of a host plant as an epiphyte or internally as an endophyte could play important roles in the natural ecology of the C. acutatum SC (Damm et al. 2012; Peres et al. 2005). Since integrated management of the C. acutatum SC depends on understanding and disrupting the

${ }^{\dagger}$ Corresponding author: K. A. Peter; kap22@psu.edu

Funding: This work was supported by the U.S. Department of Agriculture National Institute of Food and Agriculture (Project PEN04694 and accession number 1018736), the Northeast Sustainable Agriculture Research and Education (SARE) Program (subaward GNE16-180-32231), the State Horticultural Association of Pennsylvania, and the National Science Foundation (Graduate Student Fellowship Program).

*The $e$-Xtra logo stands for "electronic extra" and indicates there are supplementary materials published online.

The author(s) declare no conflict of interest.

(C) 2021 The American Phytopathological Society isolates from leaves were pathogenic on apples, and multilocus sequence analysis showed $100 \%$ identity between most isolates from leaves and diseased fruits. Apple leaves endophytically infected with $C$. fioriniae were present in a conventionally managed orchard and abundant in an untreated orchard. These lines of evidence, in the context of previously published research, lead us to hypothesize that the main ecological role of C. fioriniae is that of a leaf endophyte, which we present as a generalized C. fioriniae infection cycle that provides an updated framework for its integrated management in agricultural systems.

Keywords: disease control and pest management, ecology, integrated disease management, mycology, plant pathogen, spore dispersal

disease cycle (Peres et al. 2005; Wenneker and Thomma 2020), determining the natural ecological role and range of these species and how that fits into the disease cycle becomes crucially important.

Bitter rot disease of apple is a major problem in warm and humid apple growing regions (Sutton 2014). This disease presents itself on fruits both in the orchard mid to late season and in postharvest storage (Sutton 2014; Wenneker and Thomma 2020). It is caused by numerous Colletotrichum species within the C. gloeosporioides SC and $C$. acutatum $\mathrm{SC}$, with $C$. fioriniae being one of the most common, especially in the eastern United States (Grammen et al. 2019; Jones et al. 1996; Khodadadi et al. 2020; Munir et al. 2016; Oo et al. 2018). While species within the $C$. gloeosporioides SC are known to cause the apple leaf disease Glomerella leaf spot, the C. acutatum SC has been isolated from apple leaves but never confirmed as an apple leaf pathogen (Børve and Stensvand 2017; Velho et al. 2019).

The $C$. acutatum SC is spread by conidia that are rain-splash dispersed, thus limiting dispersal to the distance traveled by winddriven rain (Peres et al. 2005). If $C$. fioriniae has a largely pathogenic lifestyle, then infected fruit and twigs would be a primary inoculum source; however, if it has a largely endophytic or epiphytic lifestyle, removing infected fruits and twigs will be insufficient and endophytic or epiphytic leaf infections in and near orchards could serve as population reservoirs and inoculum sources (Børve and Stensvand 2017; Peres et al. 2005). While C. fioriniae was previously isolated from forest plant leaves (Marcelino et al. 2009), its limited dispersal distance and endemic nature in apple orchards led us to hypothesize that there are higher quantities of C. fioriniae conidia being dispersed in orchards where it is known to be a common pathogen than in nearby diverse deciduous woodlots and forests where $C$. fioriniae is only known to be an epiphyte or endophyte.

The objective of this study was to collect, quantify, and compare the $C$. acutatum SC conidia being dispersed in a heavily bitter-rotinfected orchard and nearby forested woodlots in south central Pennsylvania. Leaves of various broadleaf forest plants were further assessed for the presence, quantity, and identity of Colletotrichum 
endophytes. The results were combined into a generalized C. fioriniae infection cycle that sheds light on our understanding of its ecological role and provides an updated framework for its integrated management in agricultural systems.

\section{MATERIALS AND METHODS}

Trapping of rain-splashed conidia. Rain-splashed spore traps were constructed with Falcon 225-ml polypropylene conical centrifuge tubes (Corning Inc., Corning, NY) and household-grade 13-cm plastic funnels by drilling a hole in the centrifuge tube cap, inserting the funnel, and gluing them together (Supplementary Fig. S1A). The centrifuge tube could then be unscrewed from the funnel and replaced as needed. A wire sink strainer was placed in the funnel to keep out large debris. The spore traps were placed in apple orchards and forested woodlots on the Pennsylvania State University Fruit Research and Extension Center (PSU FREC) in Biglerville and Arendtsville, Pennsylvania, and at Hollabaugh Bros. Inc. orchard in Biglerville, Pennsylvania (example photos in Supplementary Fig. S1B, C, and D).

The orchard spore traps were located two per tree in and under the canopy, about $50 \mathrm{~cm}$ and 1 to $2 \mathrm{~m}$ off the ground, both within a meter of the trunk. All trees were on semidwarfing rootstocks. For our positive controls, a single Honeycrisp tree in 2018 and a Honeycrisp tree and a Rome tree in 2019 had C. fioriniae bitter-rot-infected apples hung in onion bags in the tops of the trees from bloom to harvest to maximize disease pressure. No fungicides were applied to these trees during the season. Our noninoculated test locations consisted of sites both with and without fungicide treatments. A Honeycrisp tree, a Rome tree, and a Delicious tree in 2018 and a Honeycrisp tree and a Rome tree in 2019 were noninoculated and had no fungicide treatments. Two Gala and three Honeycrisp trees in both 2018 and 2019 were noninoculated and received standard fungicide treatments as recommended for commercial orchards.

Two of the forested woodlot spore traps were in a successional forest that was meadow in the early 1990s and consisted of deciduous trees about 10 to $12 \mathrm{~m}$ high with trunks 10 to $20 \mathrm{~cm}$ in diameter. The other three traps were in a mature mostly deciduous forest woodlot with tree-trunk diameters up to $80 \mathrm{~cm}$. The traps were hung in wire hoops on wooden posts 50 to $100 \mathrm{~cm}$ off the ground.

Samples were collected from April through October 16 times in 2018 and 17 times in 2019. Spores were collected within $24 \mathrm{~h}$ after a rain, no more than once a week, and only after sufficient rainfall to fill the bottles at least one-quarter full. After processing of the sample, bottles were handwashed with soap and bleach in warm water. Before reattachment of a clean bottle, funnels were cleaned by spraying with $1 \%(0.05 \% \mathrm{NaClO})$ bleach solution.

Detection and quantification of $C$. acutatum SC conidia. The volume of water in each bottle was recorded, and the bottles were centrifuged in a two-step process in an Eppendorf 5810R centrifuge (Eppendorf North America, Hauppauge, NY). The steps consisted of $8 \mathrm{~min}$ at 4,000 rcf and decanting of all but 20 to $30 \mathrm{ml}$ of water in a process that often dislodged the pellet, then a second centrifugation of $8 \mathrm{~min}$ at 4,000 rcf and decanting of the remaining water.

DNA was extracted from the pellet using the NucleoSpin Soil DNA extraction kit (Macherey Nagel, Bethlehem, PA) with the following modifications. For step 1, $500 \mathrm{ml}$ of buffer SL2 was pipetted into the centrifuge tube and used to dislodge the pellet, which was transferred with a pipette to the bead tube. After addition of Enhancer SX in step 3, the sample was lysed by using a Macherey Nagel bead tube holder attached to a Vortex Genie (Scientific Industries, Bohemia, NY) at maximum speed for $12 \mathrm{~min}$. The rest of the DNA extraction followed protocol, which was finished by eluting the purified DNA with $50 \mu \mathrm{l}$ of buffer SE. A negative control (no initial pellet) was included in every DNA extraction to check for contaminated reagents.

C. acutatum SC DNA was detected and quantified with quantitative PCR (qPCR) using the methods of Debode et al. (2009). Briefly, a TaqMan-based assay (Thermo Fisher Scientific, Waltham, MA) targeted the $18 \mathrm{~S}$ to $5.8 \mathrm{~S}$ internally transcribed spacer (ITS1) region using primers CaITS_F701 and CaITS_R699 and probe CaITS_P710 with a QSY quencher and FAM fluorescer that is specific to the $C$. acutatum SC (Table 1). Primers were synthesized by Integrated DNA Technologies (Skokie, IL), and the PCR plates and optically clear strip caps were from VWR (Radnor, PA). The assay was run on a Bio-Rad C1000 thermocycler with the CFX96 detection system (Bio-Rad Laboratories Inc., Hercules, CA) set at $2 \mathrm{~min}$ at $50^{\circ} \mathrm{C}$ then $10 \mathrm{~min}$ at $95^{\circ} \mathrm{C}$ followed by 40 cycles of $15 \mathrm{~s}$ at $95^{\circ} \mathrm{C}$ and $30 \mathrm{~s}$ at $60^{\circ} \mathrm{C}$. A standard curve was created by counting suspensions of $C$. fioriniae spores from three separate isolates (Shlgl2 and Shlgl4 from bitter-rot-infected apples and FREC98 from grape with ripe rot, identified as $C$. fioriniae by morphology and DNA sequencing) with a hemocytometer, taking a calculated $1 \times 10^{7}$ spores from each suspension and extracting DNA using the method described above. The three samples were

TABLE 1. Primers and probes used for quantitative PCR and multilocus sequence analysis

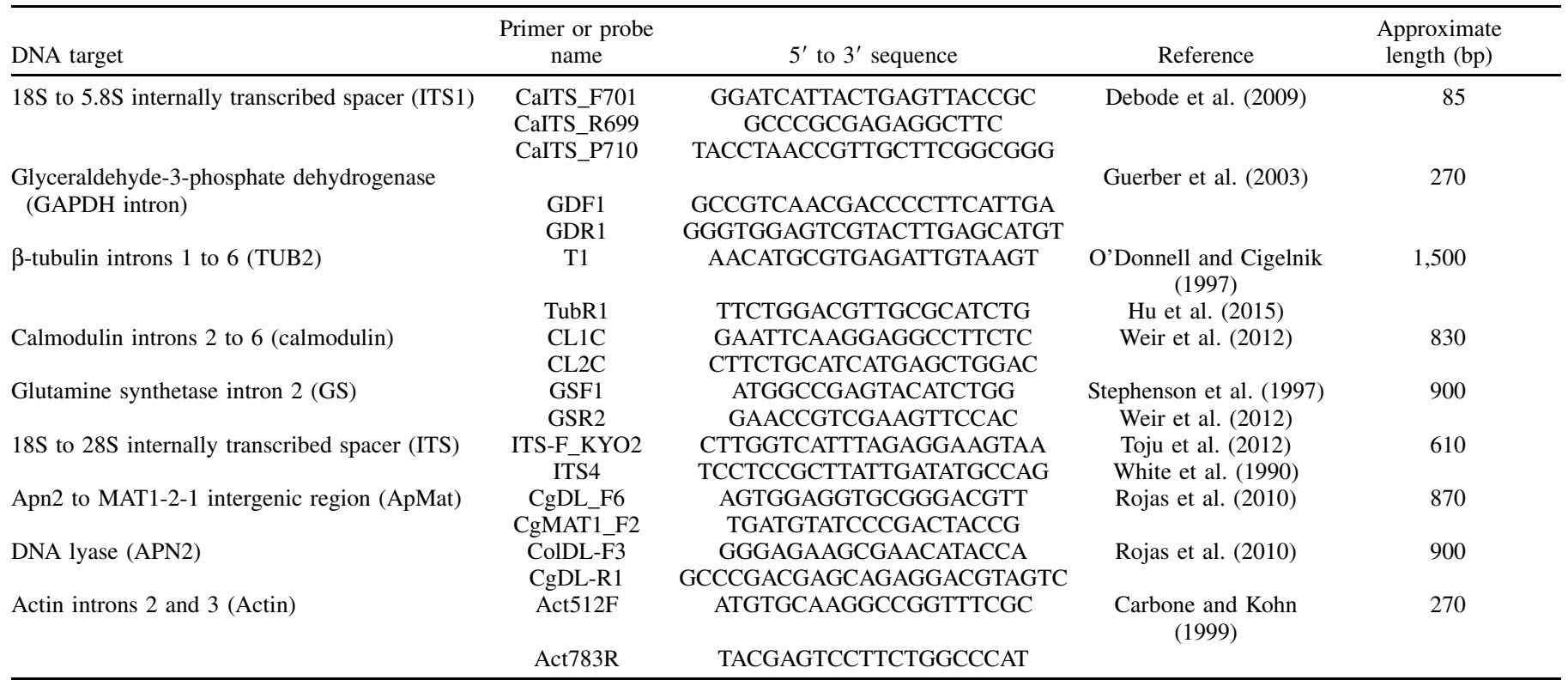


analyzed with the qPCR assay for variation, then combined into a single sample and serially diluted 10 -fold from $1 \times 10^{7}$ to $1 \times 10^{3}$ conidia equivalents. DNA standards of $1 \times 10^{7}, 1 \times 10^{6}, 1 \times 10^{4}$, and $1 \times 10^{3}$ were added to each qPCR run as an internal standard to equate cycle number to conidia number. All samples were run in duplicate and the mean average was obtained.

Detection and quantification of endophytic Colletotrichum infections in leaves. To test for the presence, abundance, and distribution of endophytic leaf infections, leaves of apple trees and numerous forest plants (Fig. 1) were collected during the months of June to September from the orchard and forested area surrounding the spore traps at PSU FREC and from Michaux State Forest (MSF), mostly within a kilometer of $\mathrm{N} 40.034086, \mathrm{~W}$ -77.342036. Permit number SFRA-1920 was obtained from the Bureau of Forestry of the Pennsylvania Department of Natural Resources for the collection of leaves from MSF. MSF covers 35,000 ha in the South Mountain area, which spans Adams, Cumberland, and Franklin counties of Pennsylvania. This area of MSF was heavily logged in the 1800s and saw commercial activity up to the 1970s but has been forested since then. The sampled area is at least 4 straightline $\mathrm{km}$ from the nearest agricultural fields. Plant species were identified based on morphology as per Rhoads and Block (2007).

A freezing method based on Børve and Stensvand (2017) and Mertely and Legard (2004) was used to detect asymptomatic
Colletotrichum spp. infections in leaves. Leaves were surface disinfected by submersion in $70 \%$ ethanol to break the water surface tension, rinsed in deionized water, submersed in $10 \%(0.5 \%$ $\mathrm{NaClO}$ ) bleach for $40 \mathrm{~s}$, rinsed in deionized water, submersed in $70 \%$ ethanol for $20 \mathrm{~s}$, and rinsed again in deionized water. They were then placed on a rack in a plastic tub with wet paper towel to maintain high humidity, frozen solid in a -20 or $-80^{\circ} \mathrm{C}$ freezer to kill the leaves, and incubated at room temperature $\left(21\right.$ to $\left.23^{\circ} \mathrm{C}\right)$ for 2 weeks to allow asymptomatic fungi to sporulate. Deionized water was sprayed on the leaves as needed to maintain moist conditions. Colletotrichum spp. spores were identified by the presence of characteristic orange conidial spore masses.

After observation that the area of spores on the leaves varied widely, photographs were taken of the leaves for calculation of the percentage of leaf surface area covered by conidial masses. Automated software was unable to accurately differentiate between the orange spores and the brown leaves, so ImageJ software (Schneider et al. 2012) was used to manually trace the outline of each leaf and the area of each leaf with orange spores. The pixels of orange spore area were divided by the pixels of total leaf area to obtain a percentage of leaf area with orange spores.

Collection and identification of Colletotrichum isolates. For isolates from leaves, orange conidial masses were randomly selected from a few leaves of various plant species and streaked onto Petri dishes of half-strength potato dextrose agar (PDA; Difco,

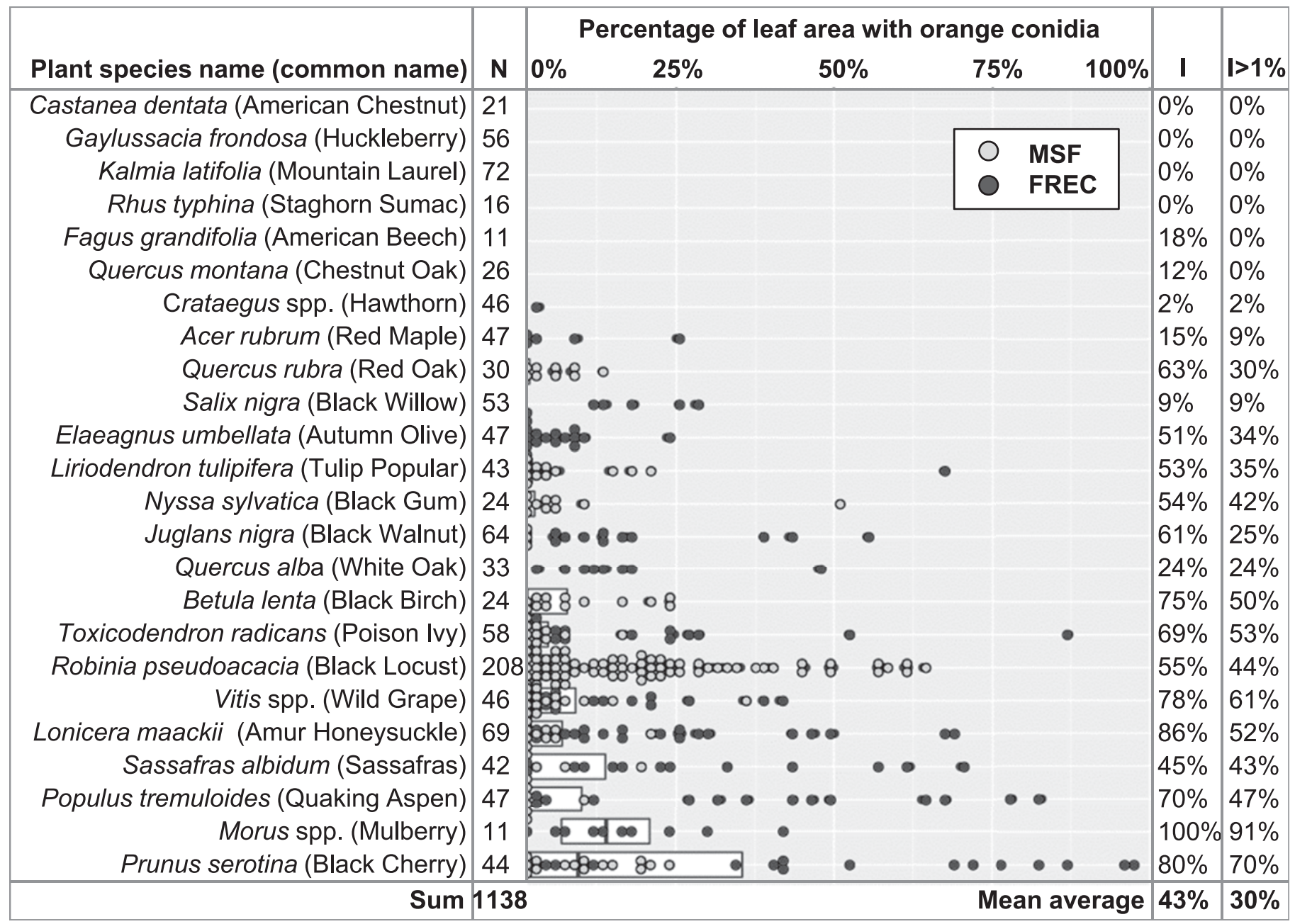

Fig. 1. Quantification of endophytic Colletotrichum infections in leaves of forest plants showing the high variability by location and within and between plant species. The plant species column has the names of plant species from which leaves were sampled. The graph is a dot plot overlaid with a box plot of the percentage of each leaf surface with orange conidia, with leaves from Michaux State Forest (MSF) in light gray and from the Pennsylvania State University Fruit Research and Extension Center (FREC) in black. $\mathrm{N}=$ number of leaves sampled of each plant species, $\mathrm{I}=$ incidence of leaves of each plant species with orange conidia, and $\mathrm{I}>1 \%=$ incidence of leaves with over $1 \%$ of surface area with orange conidia. 
Franklin Lakes, NJ), amended as need with streptomycin at 100 ppm to prevent bacterial growth. For isolates from fruit, the fruit flesh at the edge of Colletotrichum infections in apples, pears, peaches, and grapes from PSU FREC was plated on half-strength PDA. The resulting fungal growths were single-spore or hyphal-tip isolated to form genetically uniform fungal cultures. DNA was extracted from the culture with the NucleoSpin Microbial kit (Macherey Nagel), and intron 1 of the glyceraldehyde-3-phosphate dehydrogenase (GAPDH) gene, widely used in Colletotrichum identification (Vieira et al. 2020), was sequenced (Table 1).

Additional genes of a subset of the fungal cultures from each GAPDH sequence variant were sequenced to confirm the species identity. For isolates in the $C$. acutatum SC, the genes were $\beta$-tubulin (Tub2), calmodulin, and glutamine synthetase (GS); for isolates in the C. gloeosporioides SC, the additional genes Apn2 to MAT1-2-1 intergenic region (ApMat) and DNA lyase (APN2) were used (Table 1). For a few unresolved isolates, the actin gene was also sequenced; for non-Colletotrichum isolates, the ITS gene was used (Table 1).

PCR conditions were denaturation at $94^{\circ} \mathrm{C}$ for $5 \mathrm{~min}$, followed by 35 cycles of denaturation at $94^{\circ} \mathrm{C}$ for $30 \mathrm{~s}$; annealing at $55^{\circ} \mathrm{C}$ for all genes except APN2 and Actin $\left(58^{\circ} \mathrm{C}\right)$ for $30 \mathrm{~s}$; and elongation at $72^{\circ} \mathrm{C}$ for $30 \mathrm{~s}$ for GAPDH, $45 \mathrm{~s}$ for Actin, $60 \mathrm{~s}$ for calmodulin, GS, and ITS, $80 \mathrm{~s}$ for ApMat, and $120 \mathrm{~s}$ for Tub2, with a final elongation of $72^{\circ} \mathrm{C}$ for $7 \mathrm{~min}$. The PCR product was verified by gel electrophoreses and purified and sequenced in both directions by Eurofins Genomics

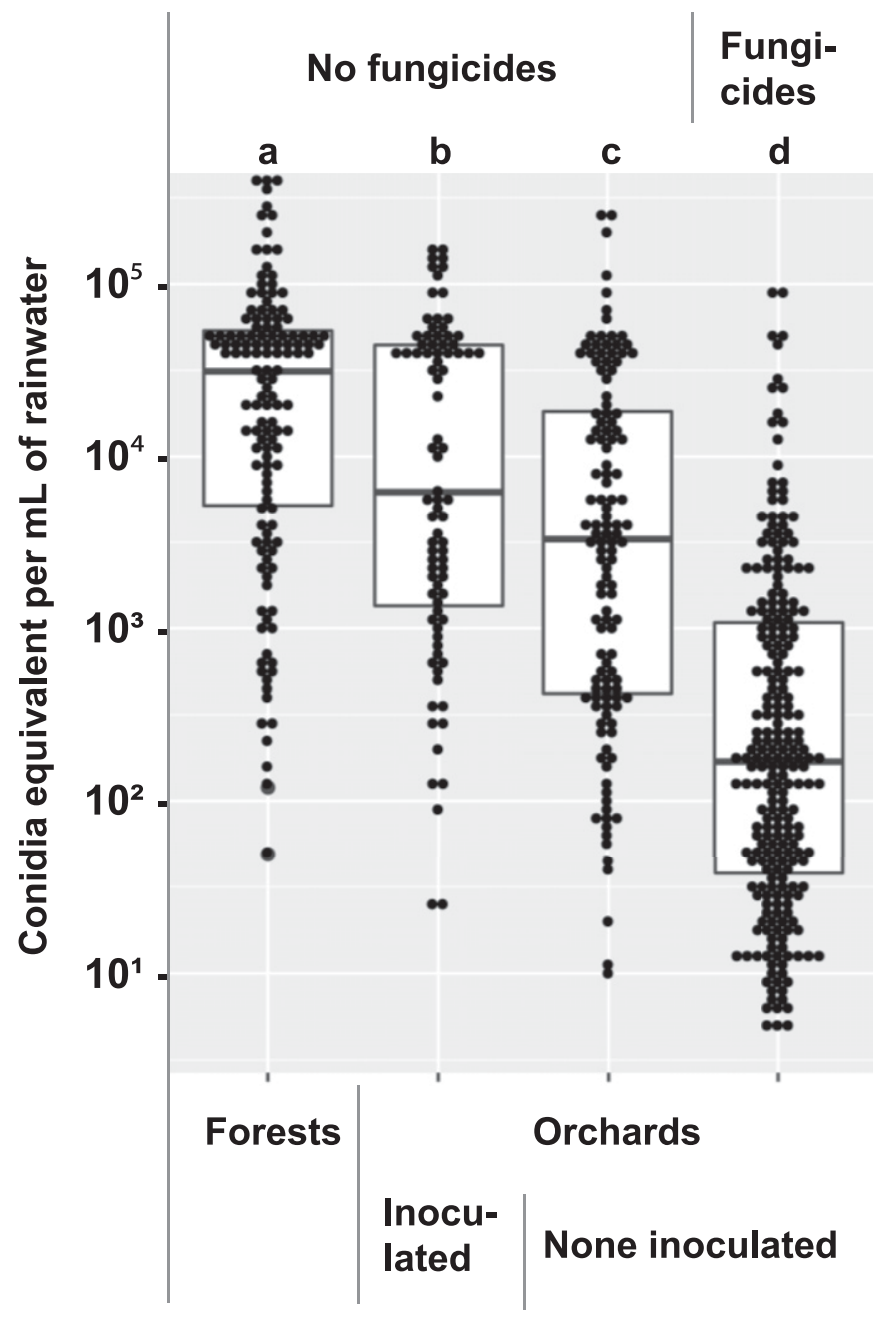

Fig. 2. Dot plot overlaid with a box plot of the conidia equivalent in each rain trap collection from the forest and orchard sites from 2018 and 2019, as quantified by quantitative PCR. Locations with a different letter are statistically different per a Tukey-Kramer test with an $\alpha$ of 0.05 .
(Louisville, KY). The forward and reverse DNA sequences were concatenated with CodonCode Aligner 7.0 software (Centerville MA), the contigs were aligned with MEGA (Kumar et al. 2018), manually checked for accuracy, and trimmed to uniform lengths. Individual genes were BLAST searched on GenBank to match previously described species, and sequences of the type strains were added to the DNA alignments. Maximum parsimony and maximum likelihood phylogenies and bootstrap analysis were performed on concatenated GAPDH, $\beta$-tubulin, calmodulin, and GS genes. Maximum parsimony was performed with PAUP version 4 (Swofford 2003) using a heuristic search. Settings were set to keep optimal trees only, starting trees for branch swapping by stepwise addition and swapping on best only, using random stepwise addition with 10 reps, 0 seed, and holding one tree at each step, and branch swapping with the TBR algorithm using a reconnection limit of 8 and swapping on best trees only, followed by a bootstrap analysis to 10,000 replicates. Maximum likelihood was performed with GARLI 2.01 on XSEDE in the CIPRES portal (Miller et al. 2010) with 1,000 bootstrap repetitions, searchreps set to 1 , significantopochange set to 0.01 , scorethreshforterm set to 0.025 , and all other settings to default.

Pathogenicity evaluation of collected $C$. fioriniae isolates. Koch's postulates were performed on seven $C$. fioriniae isolates that had been isolated from the fruits of grape, peach, and pear and from the leaves of Amur honeysuckle, poison ivy (from both FREC and MSF), and wild grape. Golden Delicious apples were surface disinfected by spraying with $70 \%$ ethanol and air drying. An approximately $5-\times 5-\mathrm{mm}$ wound was made in the surface of the apple at its equator, and mycelial plugs of the isolates were placed in the wound and incubated for 2 weeks at $25^{\circ} \mathrm{C}$ and a $24-\mathrm{h}$ photoperiod. Lesions were measured and photographed, and fungal colonies were isolated from the outer edge of the lesion. The fungal colonies were identified to species by sequencing of the intron in the GAPDH gene as described above.

Grower survey of bitter rot distribution patterns in orchards. To test whether forests and fence rows are a major source of inoculum and if bitter rot incidence in orchards is on a gradient with the highest incidence next to the forest, a grower survey was distributed in 2019 to apple growers through e-mail and in paper form at PSU winter tree fruit meetings. Participants were asked to check a box if any forest or fence row trees were growing within approximately $305 \mathrm{~m}$ (1,000 feet) of their apple orchard and if the pattern of bitter rot in orchards was uniformly distributed, in a gradient, or in random "hot spots."

Statistical analysis. qPCR baseline correction and quantification thresholds were set automatically by the Bio-Rad software and conidia equivalents were automatically calculated by the software based on the cycle quantification value and the internal standard curve. Results were exported to a spreadsheet where the conidia equivalents were divided by the milliliters of water in the spore trap to normalize to units of conidia per milliliter of rainwater, which

TABLE 2. Adjusted $P$ values for all pairwise comparisons of locations of spore trapping for 2018, 2019, and combined years

\begin{tabular}{lccccc}
\hline Year & Location $^{\mathrm{z}}$ & $\mathrm{F}$ & $\mathrm{O} 1$ & $\mathrm{O} 2$ & O3 \\
\hline 2018 & $\mathrm{~F}$ & - & & & \\
& O1 & $0 . \overline{70}$ & - & & \\
& O2 & $<0.0001$ & 0.010 & - & \\
2019 & O3 & $<0.0001$ & $<0.0001$ & $<0.0001$ & - \\
& F & - & & & \\
& O1 & 0.40 & - & & \\
$2018+2019$ & O2 & $<0.0001$ & 0.10 & - & \\
& O3 & $<0.0001$ & $<0.0001$ & $<0.0001$ & - \\
& F & - & & & \\
& O1 & 0.049 & - & & \\
& O2 & $<0.0001$ & 0.018 & - & \\
& O3 & $<0.0001$ & $<0.0001$ & $<0.0001$ & - \\
\hline
\end{tabular}

$\overline{\mathrm{z}} \mathrm{F}=$ forest, $\mathrm{O} 1$ = inoculated, untreated orchard, $\mathrm{O} 2=$ noninoculated, untreated orchard, and O3 = noninoculated, commercially treated orchard. Dashes indicate a $P$ value of 1 . 
were then $\log 10$ transformed for statistical analysis. Comparison of conidia numbers by location was done in a completely randomized design in SAS software using PROC GLM followed by a TukeyKramer means separation test (SAS, Cary, NC).

The percentages of leaf area covered by Colletotrichum conidia by plant species and forest location were evaluated as a completely randomized design using PROC GLM in SAS. Apple leaf and fruit infections were tested in a completely randomized design with $t$ tests in SAS or R software (R Core Team 2018). Graphs were made using R, Excel, and PowerPoint (Microsoft, Redmond, WA).

\section{RESULTS}

Detection and quantification of $C$. acutatum SC conidia. Two of the 16 collections in 2018 were removed from analysis because of contamination with copper sulfate that had been added as an experimental biocide. Three of the 16 collections in 2018 and three of the 17 collections in 2019 were removed from analysis because of contamination in the untreated control DNA extraction sample. This left 11 collections in 2018 and 14 collections in 2019 at 23 locations (five in forests, 18 in orchards). Of these collections, 44 samples were removed from analysis for being below the detection limit, and 144 samples that were above the range of the standard curve were counted as the maximum standard curve value of $10^{7}$ conidia equivalent per sample. The remaining 531 samples showed a logarithmic distribution (Fig. 2). Variances of the $\log 10$ transformed spore counts by location were $P=0.05$ per Levene's test, and location was significant at $P<0.001$. Tukey-Kramer pairwise comparison $P$ values for 2018, 2019, and combined years (Table 2) showed the same pattern both years, with higher conidia quantities in the forest samples than the orchard samples and lower conidia quantities in the fungicide-treated orchard samples than the untreated samples (Fig. 2).

Detection and quantification of endophytic Colletotrichum infections in leaves. Preliminary testing for endophytes in leaves of forest plants in 2018 revealed abundant orange spores, and isolation and sequencing of fungal colonies grown from those spores showed that most had $100 \%$ homology with $C$. fioriniae type strain accession JQ948622 (Fig. 3; Supplementary Table S1). Subsequent large-scale testing in 2019 at FREC and MSF for endophytic fungi in 1,138 leaves of forest plants revealed orange spore masses on $43 \%$ of them, and subsequent quantification of spore mass area showed that $30 \%$ of leaves had more than $1 \%$ leaf area with orange spores, with high variability both within and between plant species (Fig. 1). Comparisons of photos before and after incubation showed no indication that the $C$. fioriniae infections in the leaves were causing disease (Supplementary Table S2).

The general linear model in SAS showed that location, plant species, and the interaction of location and plant species were all highly significant predictors of infected leaf area, with $P<0.001$. Levene's test of variances of infected leaf area by plant species showed they were not equal at $P<0.0001$, either as raw data or after square root or arcsine transformations. Instead of a pairwise

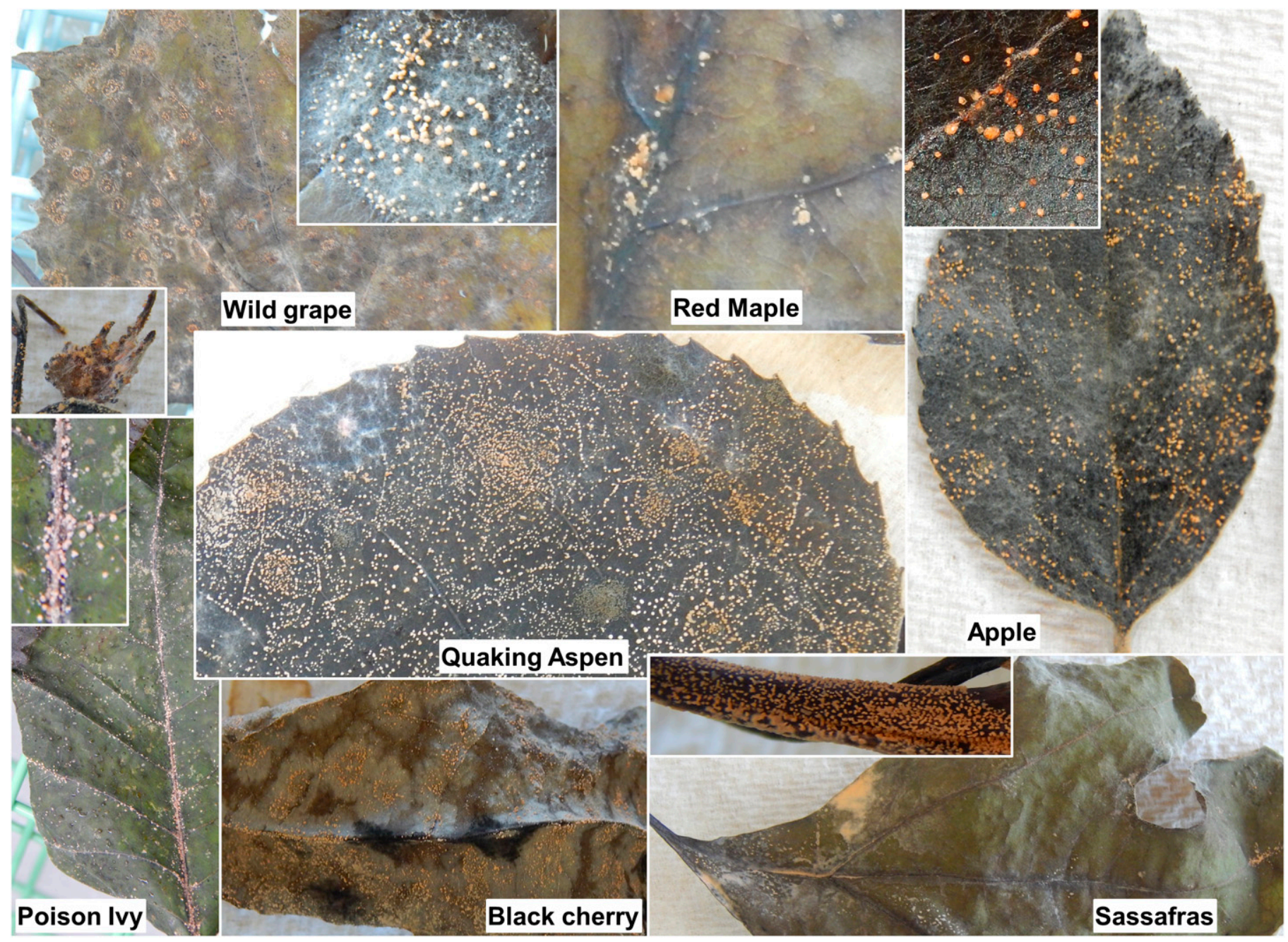

Fig. 3. Photos of a sample of leaves after surface disinfection, freezing, and incubation, showing the orange spore masses characteristic of Colletotrichum conidia. 
comparison by species, the results are shown as a dot plot of the percentage of leaf area with orange spores arranged by plant species, where every leaf with more than $1 \%$ leaf area with orange spores is shown as an individual dot (Fig. 1).

Apple leaves were collected from two commercially fungicidetreated trees and one untreated tree in 2018 and from three commercially fungicide-treated trees and five untreated trees in 2019. Leaves with endophytic infections were more abundant on untreated trees than on trees with fungicide treatments (Fig. 4). For four of the untreated trees in 2019, bitter rot incidence was obtained from 25 randomly selected apples at harvest and 1 month postharvest and recorded as cumulative incidence. When compared with the Student's $t$ test, fungicide- versus nonfungicide-treated leaves were different at $P=0.01$, and a paired $t$ test showed that leaf and fruit incidence were different at $P=0.07$ (Fig. 4).

Collection and identification of Colletotrichum isolates. Fungal colonies were obtained from the edge of rotting lesions on apple, grape, peach, and pear fruits, identified to species based on multilocus sequence analysis, and used for comparison with the colonies isolated from leaves. After it was observed that many leaves also had areas of black spores, such as those in the black cherry photo in Figure 3, several cultures were obtained for identification and comparison. Fungal colonies were obtained from orange spore masses on 97 leaves from 20 plant species and from black spore masses on four leaves from four plant species. Amplification, sequencing, and phylogenetic analysis of the GAPDH gene revealed that 87 isolates clustered with $C$. fioriniae, two with $C$. nymphaeae, two close to $C$. salix, and three in the C. gloeosporioides SC close to C. aenigma (Supplementary Figs. S1 and S2; Supplementary Table S1). Three orange-spored isolates that did not amplify with GAPDH were identified with ITS as Gnomoniopsis paraclavulata. Of the four black-spored isolates, one amplified with GAPDH and matched $C$. fioriniae, while ITS

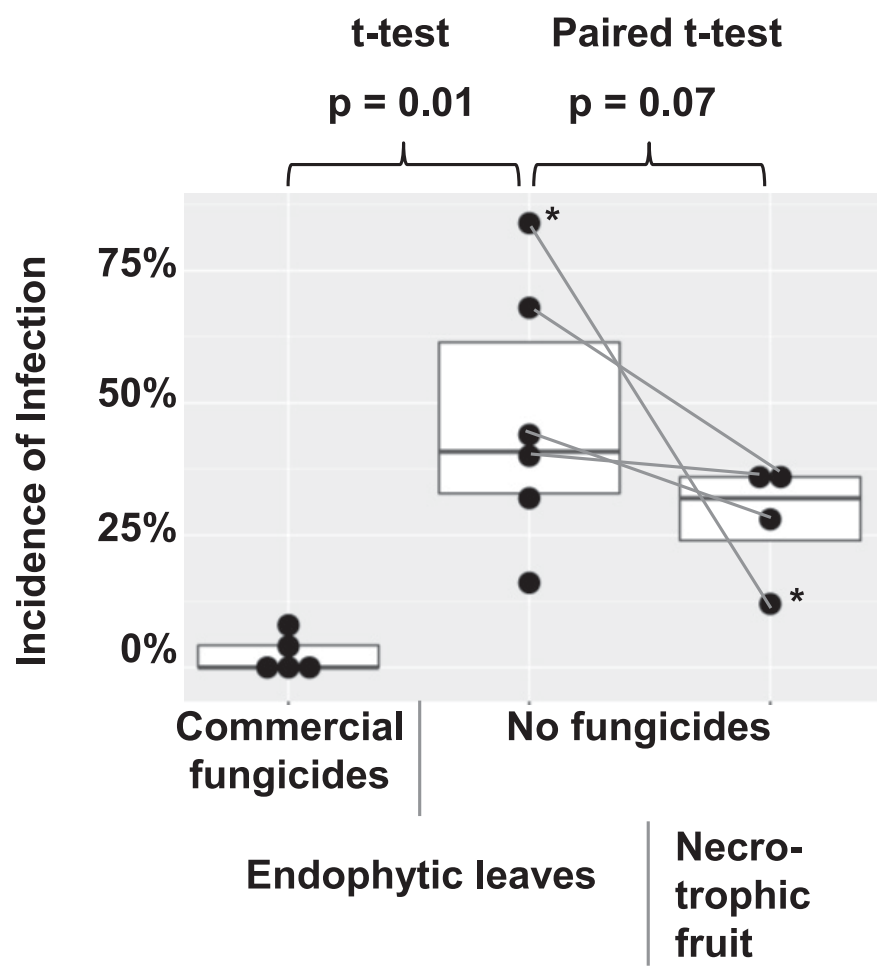

Fig. 4. Dot plot of incidence of apple leaves with endophytic Colletotrichum infections midseason and fruit with necrotrophic infections (bitter rot) postharvest, arranged by fungicide program. Each dot is a single tree and the lines are connecting leaf and fruit data from the same tree. Leaf incidence is of 24 to 28 leaves per tree and fruit incidence is of 25 fruits per tree. The tree marked with an asterisk is cultivar Rome, while the rest are Honeycrisp. identified the others as Diaporthe (Phomopsis) spp. and Pestalotiopsis spp. (Supplementary Table S1).

To confirm identity to species, a subset of 13 C. fioriniae isolates, both $C$. nymphaeae isolates, both $C$. salix isolates, and both C. gloeosporioides SC isolates, along with isolates from fruit and reference isolates from other studies, were chosen for multilocus sequence analysis using an additional four to seven genes (Table 3). The phylogeny of the isolates in the $C$. acutatum SC showed that the $C$. fioriniae and $C$. nymphaeae isolates from plant leaves are indistinguishable from those isolates from fruits, in some cases having $100 \%$ sequence identity across the four genes (Fig. 5). Isolates FREC145 and FREC146, while genetically distinct, were closest to $C$. salix. Isolates FREC139 and FREC142 grouped with and yet remained distinct from a clade that contained $C$. aenigma, $C$. hebeiense, and $C$. conoides (data not shown). BLAST search of each gene of FREC142 found $100 \%$ identity at the GAPDH loci to unidentified isolate CT03 from Peony leaves (Garfinkel and Chastagner 2018) and at the ApMat and APN2 loci to unidentified isolate Coll887 from diseased cranberry fruit (Doyle et al. 2013). Doyle et al. (2013) designated Coll887 as $C$. sp.indet.C., so we designated our matching isolates likewise.

Pathogenicity evaluation of $\boldsymbol{C}$. fioriniae isolates. After wound inoculation, the seven $C$. fioriniae isolates created typical bitter rot symptoms in the Golden Delicious apples. The fungi isolated from the edge of the necrotic lesion resembled $C$. fioriniae in culture, and DNA extraction and amplification of the GAPDH gene showed $100 \%$ sequence identity to the original isolates.

Grower survey of bitter rot distribution patterns in orchards. Of the 27 apple growers that filled out the survey on bitter rot distribution, 16 reported having forest and/or fence row trees within 1,000 feet of their orchard. Bitter rot was mostly either uniformly distributed or in hot spots, with only one grower reporting a gradient across the orchard (Fig. 6). The grower who reported a gradient also checked the boxes for uniformly distributed and hot spots and did not report forest and/or fence row trees within 1,000 feet of the orchard.

\section{DISCUSSION}

Contrary to our hypothesis, the highest quantities of conidia were in the forests and not in heavily infected orchards. The relative quantities of conidia within orchards were as expected though, with lower quantities where fungicides were applied, which supported the reliability of the detection method. The finding of high conidia quantities being dispersed in the forest led us to look for the source of those conidia and was supported by the discovery of abundant endophytic $C$. fioriniae leaf infections in many forest plants.

Detection of conidia with qPCR using the method of Debode et al. (2009) was a far better method for us than attempts at direct culturing of Colletotrichum species from environmental samples after the methods of Everett et al. (2010, 2018). Those efforts failed because of the lack of good selective growth media, difficulty of morphological identification, and abundance of other rapidly growing fungi (data not shown).

The freezing method (surface disinfection, freezing, and incubation) was an effective, simple, safe, low-cost method of detecting endophytic Colletotrichum infections in leaves of trees and shrubs. This method was comparable to treatment with paraquat (Biggs 1995; Cerkauskas and Sinclair 1980), giving similar results without the handling of toxic substances (Mertely and Legard 2004), and had the distinct advantage of producing living cultures that could be further identified and tested. The freezing method does seem best suited for sturdy tree and shrub leaves. Our experience using this method on small weed-like plants such as dandelion, clover, thistle, and so forth was that after freezing, the leaves collapsed from being too thin and fragile and the results of testing these plants were inconclusive (data not shown). 
The highly variable percentages of leaf areas with orange conidia indicate that some plant species are better hosts of $C$. fioriniae than others (Fig. 1). However, given the highly unequal variances and significance of location and location-plant species interaction, it is unwise to draw any firm conclusions about host preference without more data from multiple locations and years. The significance of the analyses is that, for reasons that likely include interactions between host, microbiome, and microclimate, infected leaf area is highly variable, within a species, by species, and by location.

Culturing of the orange conidial masses from leaves showed that the vast majority were Colletotrichum species, and specifically, C. fioriniae. The most likely explanation for the single black-spored isolate that was identified as C. fioriniae (FREC121; Supplementary Table $\mathrm{S} 1$ ) is that since it was from a leaf that had both orange

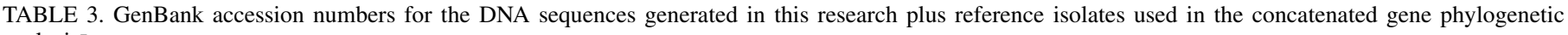
analysis $^{\mathrm{z}}$

\begin{tabular}{|c|c|c|c|c|c|}
\hline Species & Isolate & GAPDH & $\beta$-tubulin & Calmodulin & GS \\
\hline Colletotrichum acerbum & CBS: $128530^{*}$ & JQ948790 & JQ950110 & & \\
\hline C. acutatum & CBS:112996* & JQ948677 & JQ005860 & & \\
\hline C. australe & CBS:116478* & JQ948786 & JQ950106 & & \\
\hline \multirow[t]{22}{*}{ C. fioriniae } & CBS:129938 & JQ948626 & JQ949947 & & \\
\hline & EHS58* & JQ948622 & JQ949943 & MN895514 & EF593353 \\
\hline & FREC51 & MN895545 & MN895570 & MN895520 & \\
\hline & FREC58 & $\overline{\mathrm{MN895546}}$ & $\overline{\text { MN895571 }}$ & $\overline{\text { MN895521 }}$ & \\
\hline & FREC60 & $\overline{\mathrm{MN895547}}$ & $\overline{\text { MN895572 }}$ & $\overline{\text { MN895522 }}$ & \\
\hline & FREC69 & $\overline{\mathrm{MN895548}}$ & MN895573 & $\overline{\mathrm{MN895523}}$ & \\
\hline & FREC84 & MN895549 & $\overline{\mathrm{MN895574}}$ & $\overline{M N 895524}$ & MN895593 \\
\hline & FREC85 & $\overline{\mathrm{MN895550}}$ & MN895575 & $\overline{\mathrm{MN895525}}$ & $\overline{\mathrm{MN895594}}$ \\
\hline & FREC93 & MN895551 & MN895576 & MN895526 & $\overline{\mathrm{MN895595}}$ \\
\hline & FREC95 & MN895552 & $\overline{\text { MN895577 }}$ & MN895527 & $\overline{\mathrm{MN895596}}$ \\
\hline & FREC102 & MN895540 & $\overline{\mathrm{MN895565}}$ & $\overline{\mathrm{MN895515}}$ & MN895589 \\
\hline & FREC110 & MN895541 & MN895566 & MN895516 & $\overline{\mathrm{MN895590}}$ \\
\hline & FREC119 & $\overline{\mathrm{MN895542}}$ & $\overline{\text { MN895567 }}$ & $\overline{\text { MN895517 }}$ & MN895591 \\
\hline & FREC128 & MN895543 & MN895568 & MN895518 & $\overline{\text { MN895592 }}$ \\
\hline & FREC137 & $\overline{\mathrm{MN895544}}$ & $\overline{\text { MN895569 }}$ & $\overline{\text { MN895519 }}$ & \\
\hline & Hlb2 & $\overline{\text { MN895553 }}$ & $\underline{\mathrm{MN895578}}$ & $\overline{\mathrm{MN895528}}$ & MN895597 \\
\hline & $\mathrm{Hlb} 7$ & $\overline{\mathrm{MN895554}}$ & $\overline{\text { MN895579 }}$ & MN895529 & $\overline{\mathrm{MN895598}}$ \\
\hline & MSF1 & MN895555 & $\overline{\text { MN895580 }}$ & $\overline{\mathrm{MN895530}}$ & $\overline{\mathrm{MN895599}}$ \\
\hline & MSF8 & MN895559 & $\overline{\text { MN895584 }}$ & $\overline{\mathrm{MN895534}}$ & $\overline{\mathrm{MN895603}}$ \\
\hline & MSF12 & MN895556 & MN895581 & MN895531 & $\overline{\mathrm{MN895600}}$ \\
\hline & MSF19 & MN895557 & MN895582 & MN895532 & $\overline{\text { MN895601 }}$ \\
\hline & MSF40 & MN895533 & MN895583 & MN895533 & $\overline{\mathrm{MN895602}}$ \\
\hline C. godetiae & CBS:133.44* & $\overline{J Q 948733}$ & $\overline{J Q 950053}$ & & \\
\hline C. johnstonii & CBS:128532* & JQ948775 & JQ950095 & & \\
\hline C. kinghornii & CBS:198.35* & JQ948785 & JQ950105 & & \\
\hline C. lupini & CBS:109225* & JQ948485 & JQ949806 & & \\
\hline \multirow[t]{6}{*}{ C. nymphaeae } & CBS:515.78* & JQ948527 & JQ949848 & & \\
\hline & CBS:126507 & JQ948533 & JQ949854 & & \\
\hline & MSF32 & MN895539 & MN895564 & MN895513 & MN895588 \\
\hline & FREC96 & MN895537 & MN895562 & $\overline{\text { MN895511 }}$ & $\overline{\text { MN895586 }}$ \\
\hline & FREC97 & $\overline{\mathrm{MN895538}}$ & $\overline{\text { MN895563 }}$ & $\overline{\text { MN895512 }}$ & $\overline{\text { MN895587 }}$ \\
\hline & FREC138 & $\overline{\mathrm{MN895536}}$ & & $\overline{\mathrm{MN895510}}$ & \\
\hline C. orchidophilum & CBS:632.80* & $\overline{J Q 948481}$ & JQ949802 & & \\
\hline C. phormii & CBS:118194* & JQ948777 & JQ950097 & & \\
\hline C. pyricola & CBS: $128531 *$ & JQ948776 & JQ950096 & & \\
\hline C. rhombiforme & CBS:129953* & JQ948788 & JQ950108 & & \\
\hline \multirow[t]{4}{*}{ C. salicis } & CBS:607.94* & JQ948791 & JQ950111 & & \\
\hline & LJDY1-5 & KY995361 & KY995492 & & \\
\hline & FREC145 & MN895561 & MN895585 & MN895535 & \\
\hline & FREC146 & $\overline{\mathrm{MN895560}}$ & & & \\
\hline C. scovillei & CBS:126529* & $\overline{J Q 948597}$ & JQ949918 & & \\
\hline C. simmondsii & CBS:122122* & JQ948606 & JQ949927 & & \\
\hline \multirow[t]{2}{*}{ C. sp.indet.C } & FREC139 & MT075929 & MT075933 & MT075931 & MT075936 \\
\hline & FREC142 & $\overline{\text { MT075930 }}$ & $\overline{\text { MT075934 }}$ & $\overline{\text { MT075932 }}$ & $\overline{\text { MT075935 }}$ \\
\hline Additional sequences & & Actin & Ap-MAT & APN2 & ITS \\
\hline C. fioriniae & $\mathrm{Hlb} 2$ & & & & MT068552 \\
\hline C. nymphaeae & FREC96 & & & & $\overline{\text { MT492130 }}$ \\
\hline C. salicis & FREC145 & MT075928 & & & MT068551 \\
\hline \multirow{2}{*}{ C. sp.indet.C } & FREC139 & & MT071113 & MT071111 & $\overline{\text { MT068549 }}$ \\
\hline & FREC142 & MT075927 & $\overline{\text { MT071112 }}$ & $\overline{\text { MT071110 }}$ & $\overline{\text { MT068550 }}$ \\
\hline \multirow[t]{3}{*}{ Gnomoniopsis paraclavulata } & MSF10 & & & & $\overline{\mathrm{MT068553}}$ \\
\hline & MSF20 & & & & MT068554 \\
\hline & MSF21 & & & & $\overline{\text { MT068555 }}$ \\
\hline Diaporthe sp. & MSF35 & & & & $\overline{\mathrm{MT068556}}$ \\
\hline Pestalotiopsis sp. & MSF38 & & & & $\overline{\text { MT068557 }}$ \\
\hline
\end{tabular}

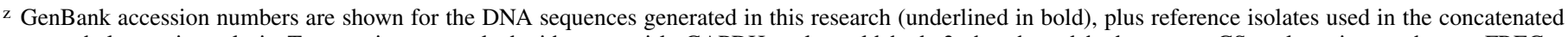
gene phylogenetic analysis. Type strains are marked with an asterisk. GAPDH $=$ glyceraldehyde-3-phosphate dehydrogenase, GS $=$ glutamine synthetase, FREC $=$ Pennsylvania State University Fruit Research and Extension Center, MSF = Michaux State Forest, ApMAT = Apn2 to MAT1-2-1 intergenic region, APN2 = DNA lyase, and ITS = internally transcribed spacer. 
and black conidia, a few $C$. fioriniae conidia were inadvertently plated out with the black conidia for single-spore isolation, and one of them was randomly or subconsciously selected. The three nonColletotrichum orange-spored isolates were identified with ITS as G. paraclavulata. These three isolates came from MSF from the closely related white and chestnut oaks. G. paraclavulata is described as living on white oak leaves, with orange conidia masses and conidia shapes nearly identical to those of Colletotrichum species, although the conidia are distinctly smaller (Sogonov et al. 2008). Since $C$. fioriniae was also isolated from leaves of white and

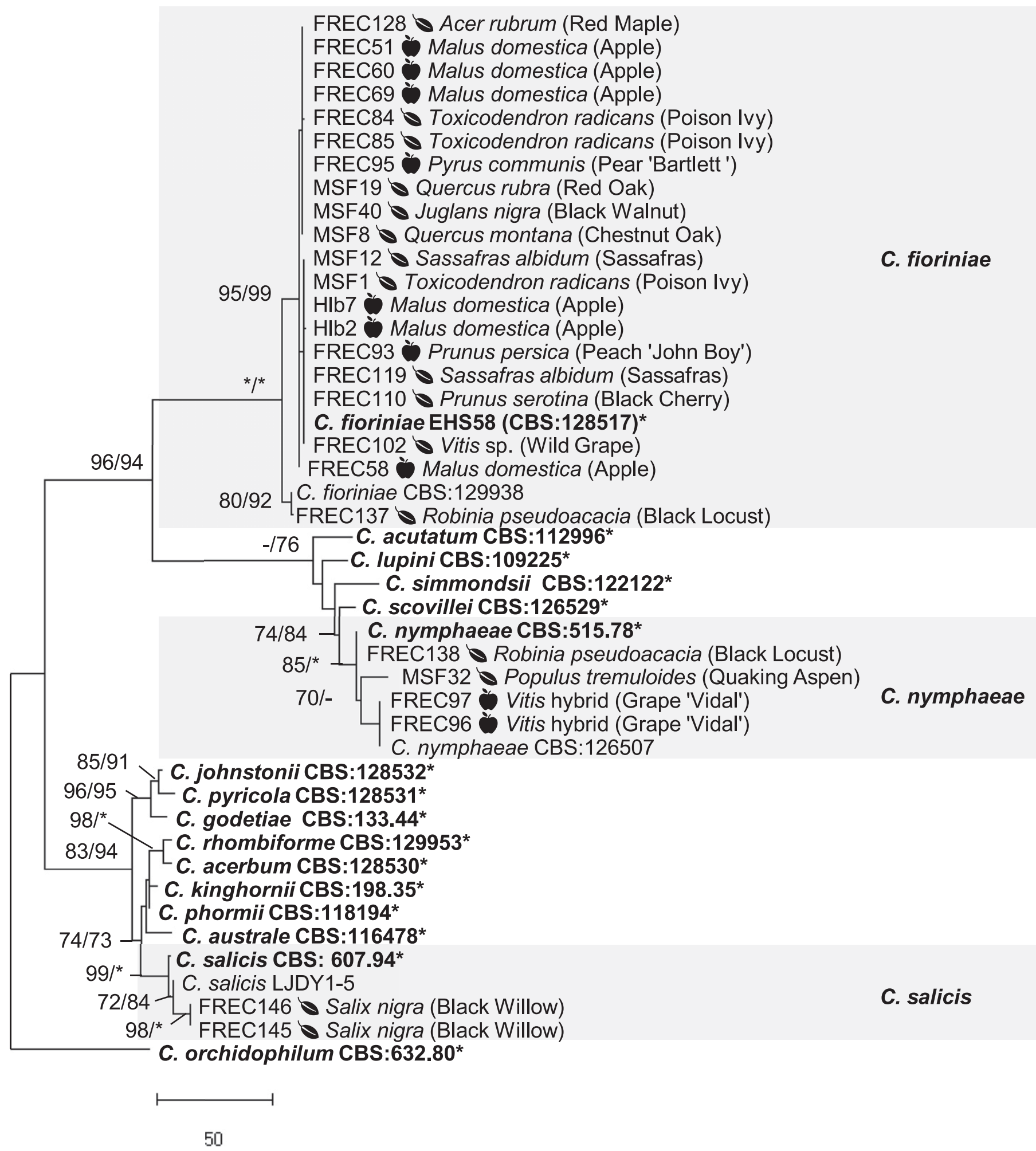

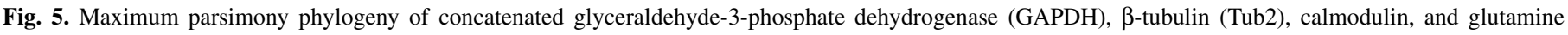

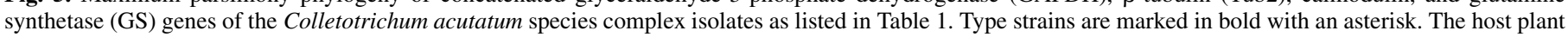

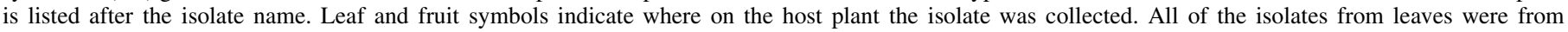

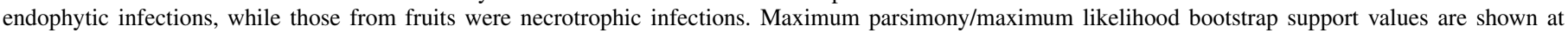

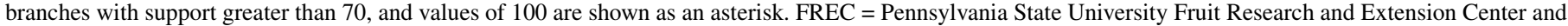
MSF $=$ Michaux State Forest. 
chestnut oaks, it should be assumed that a certain percentage of the leaf area with orange spores shown in Figure 1 of these two plant species is from G. paraclavulata. The identity of the black-spored isolates as Diaporthe (Phomopsis) spp. and Pestalotiopsis spp. is not unusual, as these are widely distributed and well-known leaf endophytes (Gomes et al. 2013; Wikee et al. 2013).

Of the non-C. fioriniae Colletotrichum isolates, $C$. nymphaeae is well known as a plant pathogen, especially on strawberry, where it is thought to come from infected nursery transplants (Wang et al. 2019). Given that we found it as a leaf endophyte on tree leaves, it is possible that some $C$. nymphaeae infections come from environmental inoculum. $C$. salicis was the only clade isolated from black willow. Our isolates were similar to and yet phylogenetically distinct from the $C$. salicis type strain on every gene available for comparison and thus is an expansion of what is considered $C$. salix or possibly a separate species altogether. $C$. sp.indet.C was also phylogenetically distinct from currently described species on every gene available for comparison. A challenge to placing this clade is that the two genes with the most resolving power, ApMat and APN2 (Vieira et al. 2017), are not available for comparison in the closely related $C$. hebeiense and $C$. conoides.

The main species identification result was that about $90 \%$ of sampled orange conidial masses across 20 plant species were C. fioriniae. This finding concurs with another study of endophytic C. fioriniae infections in leaves of forest plants (Marcelino et al. 2009). We therefore think it is safe to assume that about $90 \%$ of the conidia equivalents detected with qPCR were from $C$. fioriniae. To our knowledge, this is the first time that $C$. fioriniae conidia dispersal in a forest or endophytic infections in leaves of forest plants has been quantified. The importance of $C$. fioriniae as a plant pathogen raises the question of whether the population of endophytic isolates in forest leaves is the same as those causing disease. While tests of subspecies-level genetic resolution such as microsatellites and next-generation sequencing-based methods are needed to definitively answer this question, the results of the Koch's postulates test and the $100 \%$ sequence identity of multiple genes from endophytic infections and diseased fruit indicate that they are the same population.

The conclusion that the primary ecological role of $C$. fioriniae is that of a nonpathogen is supported by abundant leaf infections that are not correlated with lesions (Supplementary Table S2) on leaves of numerous plants for which it has not been identified as a pathogen. The conclusion that $C$. fioriniae is primarily an endophyte and not an epiphyte on asymptomatic plant tissue is supported by finding $C$. fioriniae in leaves surface treated with bleach and ethanol, which should have killed any epiphytes. While most studies of the $C$. acutatum $\mathrm{SC}$ have focused on its pathogenic role, these conclusions are consistent with previous research (Berrie and Burgess 2003; Børve and Stensvand 2017; Damm et al. 2012; Frare et al. 2016; Freeman et al. 2001; Marcelino et al. 2009; Parikka and Lemmetty 2009, 2012; Parikka et al. 2014; Peres et al. 2005; Shear and Wood 1913; Stensvand and Børve 2008; Velho et al. 2019).

The lifestyles of epiphytes and endophytes are not mutually exclusive, however, as all infections would be epiphytic from germination of the spore up to the point of penetration into the plant. Whether the infection will remain epiphytic or penetrate the host and become endophytic seems to depend on many complex variables, of which nutrient availability is a key factor. On growth media, conidia germinate to form undifferentiated mycelial masses that produce abundant secondary conidia; in water drops on glass slides, conidia germinate and form short germ tubes with appressoria and little to no secondary conidia (Damm et al. 2012; Shear and Wood 1913). On plant surfaces with adequate nutrients, such as provided by plant and floral extracts, conidia will germinate into mycelia and produce secondary conidia without necessarily producing appressoria and penetrating the host; on plant surfaces with limited nutrients, fewer secondary conidia and potentially more appressoria are produced with more penetration into the host plant, although appressoria formation is regulated by additional complex factors (Blakeman and Parbery 1977; Hasselbring 1906; Horowitz et al. 2002; Leandro et al. 2001, 2003a, b; MacKenzie et al. 2010; Parbery and Blakeman 1978; Waller et al. 2018; Zulfiqar et al. 1996).

While the abundance of endophytic leaf infections indicates that C. fioriniae is primarily a leaf endophyte, it is probable that conidia production comes from both epiphytic and endophytic infections. Similar to how a hemibiotrophic lifestyle can offer a "best of both worlds" strategy, the epiphytic/endophytic lifestyle allows growth to occur wherever nutrients are present. However, the general scarcity of nutrients on leaf surfaces, combined with ultraviolet radiation and desiccation, supports the view that $C$. fioriniae is primarily an endophyte, with transient epiphytic stages after spore germination and when nutrients are readily available.

During the growing season, rainfall would spread conidia from leaf to leaf throughout the forest canopy. The production of airdispersed ascospores from leaves is possible; however, since the sexual stage of the $C$. acutatum $\mathrm{SC}$ is rare and was not described until 36 years after the species was named (Guerber and Correll 2001), dispersion by ascospores seems unlikely. Endophytically infected leaves that fall to the ground could be possible sources of inoculum for the next year (Everett et al. 2018). However, given that the $C$. acutatum $\mathrm{SC}$ is predominately rain-splashed dispersed (Peres et al. 2005) and rain-splashed conidia mostly land no more than a meter above or beside the source (Ntahimpera et al. 1998, 1999), it seems unlikely that leaves on the ground are a primary source of inoculum.

It seems most likely that $C$. fioriniae in the forest overwinters in tree and shrub canopies. Over 100 years ago, infected fruit mummies and branch and twig cankers were identified as the main sources of overwintering bitter rot inoculum in apple trees (Roberts 1918; Von Schrenk and Spaulding 1903), although it is likely that they were dealing with several Colletotrichum spp. The importance of fruit mummies and bark and twig cankers is supported by work in apple (Nekoduka et al. 2018), holly (Lin and Hand 2019), and strawberry (Wilson et al. 1992). Fruit scars were identified as a key overwintering source in apple in Japan (Nekoduka et al. 2018). Buds are also sources of overwintering inoculum in plants such as blueberry (DeMarsay 2005; Yoshida et al. 2007), sweet and sour cherry (Børve and Stensvand 2006; Stensvand et al. 2017), and apple (Børve and Stensvand 2007; Everett et al. 2018). Since there generally are a much higher number of buds on an average tree or

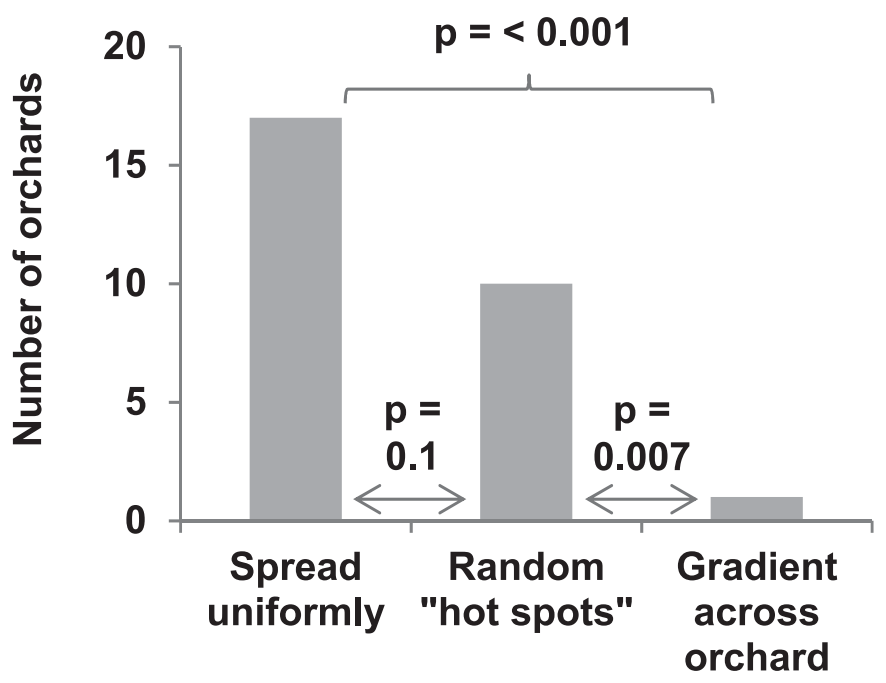

Fig. 6. Graph of sums of apple grower responses to a survey asking how bitter rot is distributed in their orchards. $P$ values were calculated by pairwise $\chi^{2}$ tests with Bonferroni corrections. 
shrub compared with the number of fruit mummies or cankers, buds could play a large role as overwintering sites even at low infection incidence.

Given the evidence discussed above, we propose an infection cycle for $C$. fioriniae in the forest (Fig. 7). It assumes that reproduction is dominated by asexually produced, rain-splashed conidia. Endophytic infections in leaves are hypothesized to be the main site of infections throughout the growing season. In susceptible fruit bearing plants, maturing infected fruits are also a factor. Buds, fruit mummies, fruit scars, and cankers serve as overwintering sites. This infection cycle is similar to previously published infection cycles (Everett et al. 2018; Peres et al. 2005) but with a greater emphasis on endophytic infections in leaves. It is also an infection cycle and not necessarily a disease cycle, only becoming a disease cycle on plants that are stressed or have susceptible fruits.

This hypothesized infection cycle has numerous implications for management of diseases caused by $C$. fioriniae. Since it is endemic in the forest canopy, eradication from nearby areas would be impractical. However, the spatial limitations of rain-splash dispersal mean that forests are not regular sources of inoculum and likely only serve as initial inoculum sources during extreme rain and wind events, after which $C$. fioriniae becomes established in the agricultural area. This also lessens the risk of spreading fungicide resistance, since initial sources of inoculum are from nonfungicidetreated populations, where any resistance genes or alleles that have a fitness penalty are unlikely to persist. The abundance of endophytic leaf infections on agricultural plants means that while weeds are

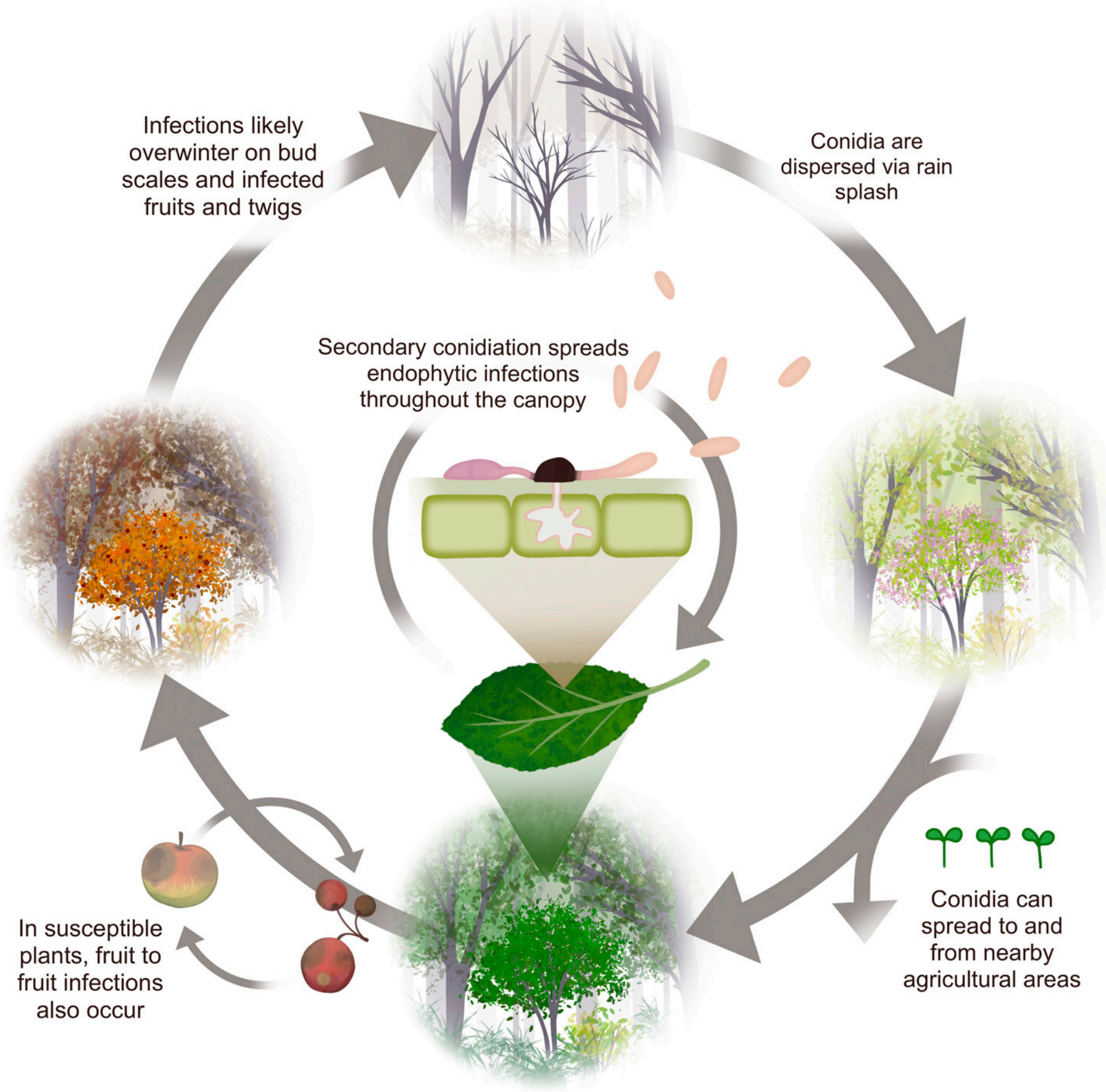

Fig. 7. Hypothesized generalized infection cycle for Colletotrichum fioriniae. This infection cycle is based mostly on endophytic leaf infections but includes necrotrophic fruit infections where susceptible fruits are present. 
potential inoculum sources, removing them is unlikely to eliminate disease since most of the inoculum might be coming from endophytic infections in the agricultural plants themselves. There could be a potential for early-season fungicide applications to reduce the amount of endophytic leaf infections as a way to reduce inoculum throughout the season. Given how widespread spore dispersal is, selecting resistant cultivars and breeding for genetic resistance in agricultural plants may be the best long-term management strategy.

It should be reiterated that the proposed infection cycle is a hypothesis to be tested and adjusted as more research results become available. The results presented in this article, which inform our management of $C$. fioriniae as a plant pathogen and our understanding of its natural ecology, add to the growing body of evidence that the main ecological role of $C$. fioriniae is that of a leaf endophyte of numerous broadleaf plants.

\section{ACKNOWLEDGMENTS}

The authors thank Hollabaugh Bros. Inc. for allowing them to trap spores in their orchard; Gabrielle Crouse, Gabriella Scolpino, and Catherine Thomas for help extracting DNA from the spore samples; Brian Lehman for help in collecting leaves from MSF; Teresa Krawczyk for help in preparing the isolates for long-term storage; Bruce L. Parker for sending them the C. fioriniae type strain; Arne Stensvand for giving a listening ear at American Phytopathological Society meetings and offering advice and encouragement; and Terrence H. Bell and the anonymous reviewers for valuable suggestions on improving the manuscript. Figure 7 was created by Sage McKeand (https://www.sagemckeand.com).

\section{LITERATURE CITED}

Berrie, A. M., and Burgess, C. M. 2003. A review of research on epidemiology and control of blackspot of strawberry (Colletotrichum acutatum) with special reference to weeds as alternative hosts. Pages 163-168 in: Proceeding of the 3rd meeting of the IOBC-WPRS Working Group "Integrated Plant Protection in Orchards", Subgroup "Soft Fruits". Dundee, Scotland. S. C. Gordon and J. V. Cross, eds. http://www.iobc-wprs.org/events/ archives.html

Biggs, A. R. 1995. Detection of latent infections in apple fruit with paraquat. Plant Dis. 79:1062-1067.

Blakeman, J. P., and Parbery, D. G. 1977. Stimulation of appressorium formation in Colletotrichum acutatum by phylloplane bacteria. Physiol. Plant Pathol. 11:313-325.

Børve, J., and Stensvand, A. 2006. Colletotrichum acutatum overwinters on sweet cherry buds. Plant Dis. 90:1452-1456.

Børve, J., and Stensvand, A. 2007. Colletotrichum acutatum found on apple buds in Norway. Plant Health Prog. doi: 10.1094/PHP-2007-052201-RS.

Børve, J., and Stensvand, A. 2017. Colletotrichum acutatum occurs asymptomatically on apple leaves. Eur. J. Plant Pathol. 147:943-948.

Carbone, I., and Kohn, L. M. 1999. A method for designing primer sets for speciation studies in filamentous ascomycetes. Mycologia 91: 553-556.

Cerkauskas, R. F., and Sinclair, J. B. 1980. Use of paraquat to aid detection of fungi in soybean tissues. Phytopathology 70:1036-1038.

Damm, U., Cannon, P. F., Woudenberg, J. H. C., and Crous, P. W. 2012. The Colletotrichum acutatum species complex. Stud. Mycol. 73:37-113.

Debode, J., Van Hemelrijck, W., Baeyen, S., Creemers, P., Heungens, K., and Maes, M. 2009. Quantitative detection and monitoring of Colletotrichum acutatum in strawberry leaves using real-time PCR. Plant Pathol. 58: 504-514.

DeMarsay, A. 2005. Anthracnose fruit rot of highbush blueberry: Biology and epidemiology. Ph.D. dissertation, Rutgers University, Rutgers, NJ.

Doyle, V. P., Oudemans, P. V., Rehner, S. A., and Litt, A. 2013. Habitat and host indicate lineage identity in Colletotrichum gloeosporioides s.l. from wild and agricultural landscapes in North America. PLoS One 8:e62394. doi.org/10.1371/journal.pone.0062394

Everett, K. R., Pushparajah, I. P. S., Timudo, A., Ah Chee, A., Scheper, R. W. A., Shaw, P. W., Spiers, T. M., Taylor, J. T., Wallis, D. R., and Wood, P. N. 2018. Infection criteria, inoculum sources and splash dispersal pattern of Colletotrichum acutatum causing bitter rot of apple in New Zealand. Eur. J. Plant Pathol. 152:367-383.

Everett, K. R., Timudo-Torrevilla, O. E., Pushparajah, I. P. S., Scheper, R. W. A., Shaw, P. W., Spiers, T. M., Chee, A. A., Taylor, J. T., Wood, P.,
Wallis, D. R., and Manning, M. A. 2010. Inoculum sources for Colletotrichum acutatum causing summer rot of apples. Orchard. 83:18-22.

Farr, D. F., and Rossman, A. Y. 2019. Fungal databases. https://nt.ars-grin.gov/ fungaldatabases/new_allView.cfm ? whichone $=$ FungusHost $\&$ thisName $=$ Colletotrichumfioriniae $\&$ organismtype $=$ Fungus $\&$ fromAllCount $=$ yes

Frare, G. F., Couto, H. T. Z., Ciampi-Guillardi, M., and Amorim, L. 2016. The causal agent of citrus postbloom fruit drop, Colletotrichum acutatum, can survive on weeds. Australas. Plant Pathol. 45:339-346.

Freeman, S., Horowitz, S., and Sharon, A. 2001. Pathogenic and nonpathogenic lifestyles in Colletotrichum acutatum from strawberry and other plants. Phytopathology 91:986-992.

Garfinkel, A., and Chastagner, G. 2018. Identification of peony diseases in the Pacific Northwest and Alaska 2018. Sustainable Agriculture Research and Education (SARE) Program report for award GW16-021. https://projects.sare.org/project-reports/gw16-021/

Gomes, R. R., Glienke, C., Videira, S. I. R., Lombard, L., Groenewald, J. Z., and Crous, P. W. 2013. Diaporthe: A genus of endophytic, saprobic and plant pathogenic fungi. Persoonia Mol. Phylogeny Evol. Fungi. 31:1-41.

Grammen, A., Wenneker, M., Van Campenhout, J., Pham, K. T. K., Van Hemelrijck, W., Bylemans, D., Geeraerd, A., and Keulemans, W. 2019. Identification and pathogenicity assessment of Colletotrichum isolates causing bitter rot of apple fruit in Belgium. Eur. J. Plant Pathol. 153:47-63.

Guerber, J. C., and Correll, J. C. 2001. Characterization of Glomerella acutata, the teleomorph of Colletotrichum acutatum. Mycologia 93:216-229.

Guerber, J. C., Liu, B., Correll, J. C., and Johnston, P. R. 2003. Characterization of diversity in Colletotrichum acutatum sensu lato by sequence analysis of two gene introns, mtDNA and intron RFLPs, and mating compatibility. Mycologia 95:872-895.

Hasselbring, H. 1906. The appressoria of the anthracnoses. Bot. Gaz. 42: 135-142.

Horowitz, S., Freeman, S., and Sharon, A. 2002. Use of green fluorescent protein-transgenic strains to study pathogenic and nonpathogenic lifestyles in Colletotrichum acutatum. Phytopathology 92:743-749.

Hu, M.-J., Grabke, A., and Schnabel, G. 2015. Investigation of the Colletotrichum gloeosporioides species complex causing peach anthracnose in South Carolina. Plant Dis. 99:797-805.

Jones, A. L., Ehret, G. R., Meyer, M. P., and Shane, W. W. 1996. Occurrence of bitter rot on apple in Michigan. Plant Dis. 80:1294-1297.

Khodadadi, F., González, J. B., Martin, P. L., Giroux, E., Bilodeau, G. J., Peter, K. A., Doyle, V. P., and Aćimović, S. G. 2020. Identification and characterization of Colletotrichum species causing apple bitter rot in New York and description of C. noveboracense sp. nov. Sci. Rep. 10: 11043.

Kumar, S., Stecher, G., Li, M., Knyaz, C., and Tamura, K. 2018. MEGA X: Molecular evolutionary genetics analysis across computing platforms. Mol. Biol. Evol. 35:1547-1549.

Leandro, L. F. S., Gleason, M. L., Nutter, F. W., Wegulo, S. N., and Dixon, P. M. 2003a. Influence of temperature and wetness duration on conidia and appressoria of Colletotrichum acutatum on symptomless strawberry leaves. Phytopathology 93:513-520.

Leandro, L. F. S., Gleason, M. L., Nutter, F. W., Wegulo, S. N., and Dixon, P. M. 2003b. Strawberry plant extracts stimulate secondary conidiation by Colletotrichum acutatum on symptomless leaves. Phytopathology 93: 1285-1291.

Leandro, L. F. S., Gleason, M. L., Wegulo, S. N., Nutter, F. W., and Dixon, P. M. 2001. Survival and sporulation of Colletotrichum acutatum on symptomless strawberry leaves. Phytopathology 91:659-664.

Lin, S., and Hand, F. P. 2019. Determining the sources of primary and secondary inoculum and seasonal inoculum dynamics of fungal pathogens causing fruit rot of deciduous holly. Plant Dis. 103:951-958.

MacKenzie, S. J., Peres, N. A., and Timmer, L. W. 2010. Colonization of citrus leaves and secondary conidiation response to citrus flower extracts by nonpostbloom fruit drop strains of Colletotrichum acutatum. Trop. Plant Pathol. 35:333-342.

Marcelino, J. A. P., Gouli, S., Parker, B. L., Skinner, M., Schwarzberg, L., and Giordano, R. 2009. Host plant associations of an entomopathogenic variety of the fungus, Colletotrichum acutatum, recovered from the elongate hemlock scale, Fiorinia externa. J. Insect Sci. 9:25.

Mertely, J. C., and Legard, D. E. 2004. Detection, isolation, and pathogenicity of Colletotrichum spp. from strawberry petioles. Plant Dis. 88: 407-412.

Miller, M. A., Pfeiffer, W., and Schwartz, T. 2010. Creating the CIPRES Science Gateway for inference of large phylogenetic trees. Pages 1-8 in: Proceedings of the Gateway Computing Environments Workshop (GCE), New Orleans, LA. IEEE, Washington, DC.

Munir, M., Amsden, B., Dixon, E., Vaillancourt, L., and Gauthier, N. A. W. 2016. Characterization of Colletotrichum species causing bitter rot of apple in Kentucky orchards. Plant Dis. 100:2194-2203. 
Nekoduka, S., Tanaka, K., and Sano, T. 2018. Epidemiology of apple bitter rot caused by Colletotrichum acutatum sensu lato. J. Gen. Plant Pathol. 84: 262-271.

Ntahimpera, N., Ellis, M. A., Wilson, L. L., and Madden, L. V. 1998. Effects of a cover crop on splash dispersal of Colletotrichum acutatum conidia. Phytopathology 88:536-543.

Ntahimpera, N., Wilson, L. L., Ellis, M. A., and Madden, L. V. 1999. Comparison of rain effects on splash dispersal of three Colletotrichum species infecting strawberry. Phytopathology 89:555-563.

O’Donnell, K., and Cigelnik, E. 1997. Two divergent intragenomic rDNA ITS2 types within a monophyletic lineage of the fungus Fusarium are nonorthologous. Mol. Phylogenet. Evol. 7:103-116.

Oo, M. M., Yoon, H. Y., Jang, H. A., and Oh, S. K. 2018. Identification and characterization of Colletotrichum species associated with bitter rot disease of apple in South Korea. Plant Pathol. J. 34:480-489.

Parbery, D. G., and Blakeman, J. P. 1978. Effect of substances associated with leaf surfaces on appressorium formation by Colletotrichum acutatum. Trans. Br. Mycol. Soc. 70:7-19.

Parikka, P., and Lemmetty, A. 2009. Colletotrichum acutatum: Survival in plant debris and infection of some weeds and cultivated plants. Acta Hortic. 842:307-310.

Parikka, P., and Lemmetty, A. 2012. Survival of Colletorichum acutatum on alternate hosts. Acta Hortic. 926:645-649.

Parikka, P., Lemmetty, A., Sundelin, T., Strømeng, G. M., and Stensvand, A. 2014. Survival of Colletotrichum acutatum in plant residue. Acta Hortic. 1117:177-180.

Peres, N., Timmer, L. W., Adaskaveg, J. E., and Correll, J. C. 2005. Lifestyles of Colletotrichum acutatum. Plant Dis. 89:784-796.

R Core Team. 2018. R: A language and environment for statistical computing. R Foundation for Statistical Computing, Vienna, Austria.

Rhoads, A. F., and Block, T. A. 2007. The plants of Pennsylvania: An illustrated manual. University of Pennsylvania Press, Philadelphia, PA.

Roberts, J. W. 1918. The sources of apple bitter-rot infections. U.S. Dept. Agric. Bull. 684:1-26.

Rojas, E. I., Rehner, S. A., Samuels, G. J., Van Bael, S. A., Herre, E. A., Cannon, P., Chen, R., Pang, J., Wang, R., Zhang, Y., and Peng, Y. Q. 2010. Colletotrichum gloeosporioides s.l. associated with Theobroma cacao and other plants in Panamá: Multilocus phylogenies distinguish host-associated pathogens from asymptomatic endophytes. Mycologia 102:1318-1338.

Schneider, C. A., Rasband, W. S., and Eliceiri, K. W. 2012. NIH Image to ImageJ: 25 years of image analysis. Nat. Methods 9:671-675.

Shear, C. L., and Wood, A. K. 1913. Studies of fungous parasites belonging to the genus Glomerella. U.S. Dept. Agric. Bull. 252:1-128.

Sogonov, M. V., Castlebury, L. A., Rossman, A. Y., Mejía, L. C., and White, J. F. 2008. Leaf-inhabiting genera of the Gnomoniaceae, Diaporthales. Stud. Mycol. 62:1-77.

Stensvand, A., and Børve, J. 2010. Sources of inoculum of Colletotrichum acutatum in cherry and apple. Pages 51-53 in: Proceedings of the IOBC-WPRS Working Group "Integrated Plant Protection in Fruit Crops", 7th International Conference on Integrated Fruit Production. Avignon, France. J. Cross, M. Brown, J. Fitzgerald, M. Fountain, and D. Yohalem, eds. http://www.iobcwprs.org/events/archives.html

Stensvand, A., Børve, J., and Talgø, V. 2017. Overwintering diseased plant parts and newly infected flowers and fruit as sources of inoculum for Colletotrichum acutatum in sour cherry. Plant Dis. 101:1207-1213.
Stephenson, S. A., Green, J. R., Manners, J. M., and Maclean, D. J. 1997. Cloning and characterisation of glutamine synthetase from Colletotrichum gloeosporioides and demonstration of elevated expression during pathogenesis on Stylosanthes guianensis. Curr. Genet. 31:447-454.

Sutton, T. B. 2014. Bitter rot. Pages 20-21 in: Compendium of apple and pear diseases and pests. American Phytopathological Society, St. Paul, MN.

Swofford, D. L. 2003. PAUP*4.0: Phylogenetic analysis using parsimony (*and other methods). Sinauer Associates, Sunderland, MA.

Toju, H., Tanabe, A. S., Yamamoto, S., and Sato, H. 2012. High-coverage ITS primers for the DNA-based identification of ascomycetes and basidiomycetes in environmental samples. PLoS One 7:e40863.

Velho, A. C., Stadnik, M. J., and Wallhead, M. 2019. Unraveling Colletotrichum species associated with Glomerella leaf spot of apple. Trop. Plant Pathol. 44:197-204.

Vieira, W. A. S., Bezerra, P., da Silva, A. C., Veloso, J. S., Camara, M. P. S., and Doyle, V. P. 2020. Optimal markers for the identification of Colletotrichum species. Mol. Genet. Evol. 143:1-19.

Vieira, W. A. S., Lima, W. G., Nascimento, E. S., Michereff, S. J., Câmara, M. P. S., and Doyle, V. P. 2017. The impact of phenotypic and molecular data on the inference of Colletotrichum diversity associated with Musa. Mycologia 109:912-934.

Von Schrenk, H., and Spaulding, P. 1903. The bitter rot of apples. B. T. Galloway, ed. U.S. Department of Agriculture, Washington, DC.

Waller, T. J., Vaiciunas, J., Constantelos, C., and Oudemans, P. V. 2018. Evidence that blueberry floral extracts influence secondary conidiation and appressorial formation of Colletotrichum fioriniae. Phytopathology 108: 561-567.

Wang, N.-Y., Forcelini, B. B., and Peres, N. A. 2019. Anthracnose fruit and root necrosis of strawberry are caused by a dominant species within the Colletotrichum acutatum species complex in the United States. Phytopathology 109:1293-1301.

Weir, B. S., Johnston, P. R., and Damm, U. 2012. The Colletotrichum gloeosporioides species complex. Stud. Mycol. 73:115-180.

Wenneker, M., and Thomma, B. P. H. J. 2020. Latent postharvest pathogens of pome fruit and their management: From single measures to a systems intervention approach. Eur. J. Plant Pathol. 156:663-681.

White, T. J., Bruns, S., Lee, S., and Taylor, J. 1990. Amplification and direct sequencing of fungal ribosomal RNA genes for phylogenetics. Pages 315-322 in: PCR protocols: A guide to methods and applications. Academic Press, New York, NY.

Wikee, S., Lombard, L., Nakashima, C., Motohashi, K., Chukeatirote, E., Cheewangkoon, R., McKenzie, E. H. C., Hyde, K. D., and Crous, P. W. 2013. A phylogenetic re-evaluation of Phyllosticta (botryosphaeriales). Stud. Mycol. 76:1-29.

Wilson, L. L., Madden, L. V., and Ellis, M. A. 1992. Overwinter survival of Colletotrichum acutatum in infected strawberry fruit in Ohio. Plant Dis. 76: 948-950.

Yoshida, S., Tsukiboshi, T., Shinohara, H., Koitabashi, M., and Tsushima, S. 2007. Occurrence and development of Colletotrichum acutatum on symptomless blueberry bushes. Plant Pathol. 56:871-877.

Zulfiqar, M., Brlansky, R. H., and Timmer, L. W. 1996. Infection of flower and vegetative tissues of citrus by Colletotrichum acutatum and C. gloeosporioides. Mycologia 88:121-128. 